\title{
Contested Interpretations of Economic Inequality Following Hurricane Katrina
}

\author{
Deborah Belle* \\ Boston University
}

\begin{abstract}
Americans are deeply divided over the meaning of the poverty and racial exclusion revealed in the wake of Hurricane Katrina. Media accounts of the hurricane riveted, angered, and depressed many Americans, but did not lead to a national consensus in favor of new policies to fight poverty and economic inequality. This article considers theories and research evidence that may help to explain this failure. Self-serving and group-serving biases lead many economically advantaged Americans to assign responsibility for poverty to individual actors, ignoring systemic factors. Motivated reasoning to justify existing economic and political systems and to maintain belief in a just world leads many, of all socioeconomic statuses, to explain economic inequalities as the result of purely individual factors. Media coverage of the hurricane may inadvertently have deflected attention from systemic causes of poverty by focusing attention on individual actors in the wake of the storm.
\end{abstract}

You are dealing with the permanently poor-people who don't have jobs, are not used to getting up and organizing themselves... and for whom sitting and waiting is a way of life.

- Linda Chavez, head of the U.S. Civil Rights Commission under President Reagan, speaking of those stranded by Hurricane Katrina

Rationales for inequality are as ubiquitous as inequality itself, and they are matched in quantity by contrary demands for equality and justifications of them.

—Robinson \& Bell (1978, p. 125)

Hurricane Katrina was one of the most closely followed news stories of recent decades, with $70 \%$ of respondents in one poll saying they paid very close

\footnotetext{
* Correspondence concerning this article should be addressed to Deborah Belle, Department of Psychology, Boston University, 64 Cummington St., Boston, MA 02215 [e-mail: debbelle@bu.edu].

The author is greateful to Michael Parker and three anonymous reviewers for suggestions which greatly strengthened this paper.
} 
attention to the story (Pew Research Center, 2005). The coverage was not only well watched, it was often emotionally powerful, with striking visual images of devastated individuals and communities. Half of those polled stated that they felt angry because of what happened in areas hit by the hurricane, 58\% stated that they felt depressed, and $56 \%$ said that they or someone in their household had already made a donation to help those affected by the hurricane (Pew Research Center, 2005).

In the aftermath of Hurricane Katrina, many observers hoped that a new national commitment to economic and social justice would be triggered by the searing images of impoverished African American communities, so vulnerable even before the hurricane struck. For such observers, the existence of poverty and racial exclusion in our wealthy nation presented a prima facie argument for political redress. For others, however, these scenes raised no moral alarms. No public actions were therefore required. Existing programs that aided the poor, such as Medicaid and food stamps, could be slashed to fund the post-hurricane clean-up effort. Prevailing wage laws and affirmative action programs could be eliminated as too onerous in a difficult time. As the New York Times headline put it, "Liberal hopes ebb in post-storm poverty debate" (DeParle, October 11, 2005). Polls conducted before and again just after Hurricane Katrina revealed only a trivial increase in Americans' beliefs that "we are becoming a society of the haves and the have-nots" (Grusky \& Ryo, 2006). Enthusiasm for government efforts to reduce economic inequality actually declined over the same time period (Grusky $\&$ Ryo, 2006).

Why did Americans respond to the same dramatic scenes in such diametrically opposed ways? Why did exposure to such scenes fail to produce changed public policies to correct the problems Hurricane Katrina made visible? In this article I review theories and research evidence bearing on these questions, arguing that the ways in which Americans responded to Hurricane Katrina were colored by our preexisting understandings of poverty and economic inequality. Americans want a society that is "fair," but fairness means different things to different people. We come to the discussion from different vantage points, some as winners in the current economy and some as losers. Our racial/ethnic identifications, our gendered experiences in the world, and our different religious traditions shape the ways we think about wealth and poverty, about rich people and poor people, about markets and government. Powerful motivations to justify and accommodate to the current economic and political system forestall potential criticisms. And, ironically, the very nature of media coverage of the hurricane's victims - its emotional focus on specific distressed individuals and communities-may have encouraged victimblaming in many viewers rather than a sense of shared societal responsibility. As debates continue about the social divisions exposed by Hurricane Katrina, this article examines several lines of research on our responses to poverty and economic inequality that may help to explain our current political disagreements as well as 
our failure to respond to Hurricane Katrina with a renewed societal commitment to eliminating poverty and racial exclusion.

\section{Economic Background}

In our founding documents, the United States of America celebrates the fundamental equality of all people, yet in the United States today, access to economic resources is becoming more and more unequal. The percentage of income going to the richest one-tenth of $1 \%$ of Americans quadrupled between 1970 and 1998, giving the richest 13,000 families almost as much income as the poorest 20 million families (Bartels, 2004). The richest $1 \%$ of American households now control a third of all national wealth, twice as much as the bottom $80 \%$ (Mishel, Bernstein, \& Allegretto, 2005). Such economic inequalities are more pronounced in the United States than in any other wealthy country. Racial disparities are immense, with the median white household having ten times the wealth of the median African American household (Mishel et al., 2005). Low-wage workers in the United States are also less likely than those in other wealthy economies to move to high-wage jobs (Mishel et al., 2005).

\section{Consequences of Economic Inequality}

Research suggests that high levels of economic inequality are associated with low levels of trust, social cohesion, and social capital. In national surveys, the extent to which Americans express trust in each other declined by approximately a third during a recent 25-year period in which economic inequality rose dramatically (Kawachi, 1999). Cross-sectional analyses reinforce this picture, showing that in U.S. states with high levels of income inequality, trust in others is far lower than in states where income is distributed more equally (Kawachi, Kennedy, Lochner, \& Prothrow-Stith, 1997). These results may be confounded with state-level variations in ethnic diversity and with historic and contemporary race relations, as the states of the deep South are among the U.S. states highest in economic inequality, with Louisiana the most economically unequal state in the nation (Sapolsky, 2004). Far away from the particular racial make-up and history of the United States, however, Putnam (1993) also found in the regions of Italy a very high negative correlation between economic inequality and social cohesion, suggesting that a universal principle may be at work.

Economic inequality appears to skew U.S social policies in favor of the wealthy at the expense of the poor and the middle class (Kawachi \& Kennedy, 1999; Wilkinson, 1996). When the rich are able to isolate themselves in gated communities and exclusive neighborhoods and buy private education and other services for their families, they easily lose touch with the experiences of those who are poor or middle class, and they have incentives to reduce their own tax payments for governmental 
expenses that do not benefit them personally. Their large discretionary incomes make campaign contributions painless, and allow them to support think tanks and media outlets that popularize ideas justifying the abandonment of public services.

The views of the nonaffluent majority can be brought into line as issues are "framed" in ways designed to appeal to this group (Bullock, Fernald, \& Radley, 2005; Lakoff, 2002). Or the views of the nonaffluent can be ignored by politicians who do not expect in any case to receive major political contributions from such constituencies. More than half the campaign contribution dollars come from the most affluent 10\% of the U.S. population (Schlozman, Brady, \& Verba, 1997). One recent analysis demonstrated that U.S. senators were very responsive to the policy preferences of their constituents from the richest third of the income distribution, somewhat less attentive to those in the middle third, and completely unresponsive to the policy preferences of the poorest third of their constituents (Bartels, 2005). Nor were these results accounted for by income-related differences in political knowledge, voting, or contact with senators.

In accord with such reasoning, public spending for education is lower and economic assistance to poor parents is more meager in U.S. states with higher levels of income inequality, controlling for the wealth of the state (Kaplan, Pamuk, Lynch, Cohen, \& Balfour, 1996). [In Louisiana, for instance, welfare benefits averaged less than \$240 per month in 2004 (Lerner, 2005)]. Not surprisingly, children in more unequal states show lower levels of educational achievement and high school completion than their peers from more egalitarian states, and unequal states then spend larger portions of their state budgets on police, prisons, and health care (Kaplan et al., 1996). All of these processes may work to retard upward mobility, thus contributing to future high levels of economic inequality in the state.

It is probably no coincidence that the United States, with the highest level of economic inequality among the wealthy nations, also provides the lowest level of governmental support to individuals and families, or that the U.S. tax burden has been shifted from wealthy families and corporations to the middle class and the poor at a time of great economic inequality. The 2001-2003 tax cuts resulted in savings of just under $\$ 600$ for middle-class families, $\$ 61$ for the poorest fifth of U.S. families, and $\$ 67,000$ for the richest $1 \%$ of U.S. families (Mishel et al., 2005). As a classic Tom Tomorrow cartoon put it, "If the poor don't like it, let'em buy their own senators!" Or, as Supreme Court Justice Louis Brandeis put it, "We may have democracy, or we may have wealth concentrated in the hands of a few, but we can't have both" (cited in Lonergan, 1941, p. 4).

\section{Inequalities and Their Justifications}

Actual levels of economic inequality and the ideologies that justify inequality may mutually reinforce one another. Della Fave (1980) has described a circular reasoning process through which individuals with wealth and power come to be 
seen, by themselves and others, as possessing other positive characteristics. Their apparent superiority then leads people to believe that they deserve to be more richly rewarded. Verba et al. (1987) found that citizens in different countries tended to endorse as appropriate the income disparities between high and low earners in their own societies, although such disparities differed markedly from one society to another. Similarly, Iyengar's (1990) survey respondents apparently used a needy family's current income level as an anchor in determining the appropriate amount of public assistance income for the family. The higher the level of current income assigned to the family in a vignette, the larger the amount of financial assistance considered appropriate for the family by survey respondents.

Such findings may be seen as illustrations of the belief in a just world (Lerner \& Miller, 1978), the human propensity to view outcomes, whether favorable or unfavorable, as somehow deserved. According to just world theory, it is painful to confront cases of apparent injustice or to regard the world as capricious and unfair, so we cling to the illusion that the world is just. We attribute both disasters and windfalls to the actions or characters of individuals. Given such inclinations, our current high level of economic inequality may actually fuel the perception that the rich deserve their wealth and the poor their poverty.

Although the belief in a just world is often understood as an illusion to which everyone is susceptible, researchers have also developed instruments to study individual differences in the tendency to believe in a just world and demonstrated substantial individual variation in this propensity. People who score high on such measures are more likely than others to derogate victims and members of underprivileged groups, to trust existing institutions and authorities, and to blame the poor and credit the rich for their economic standings (see Jost, Blount, Pfeffer, \& Hunyady, 2003).

Social dominance theorists (Sidanius \& Pratto, 1999; Sidanius, Pratto, \& Rabinowitz, 1994) argue that equality is not a fundamentally attractive condition for many humans and that, instead, there is a basic human propensity to form and maintain hierarchies among social groups. Belief in individual responsibility for economic success or failure in life and belief that we have an open, meritocratic system that adequately rewards individual endeavor are viewed within social dominance theory as "legitimizing myths" that sustain anti-egalitarian beliefs and actions.

Jost and his colleagues have provided a rich body of evidence demonstrating the existence of a powerful motive to defend, justify, and accommodate to the existing order, including those systems and institutions that affect us, such as the free market system (Jost, Banaji, \& Nosek, 2004; Jost, Blount, Pfeffer, \& Hunyady, 2003; Jost \& Hunyady, 2005). Strikingly, despite the conspicuous and increasing inequalities in U.S. society, a majority of those in the United States describe the U.S. economy as basically fair, including half of those within the lowest SES group (Jost et al., 2003). 
Endorsement of the fairness of the economy is associated with such psychological dimensions as self-deception, opposition to equality, belief in a just world, and political conservatism. Furthermore, support for the free market system appears to be strengthened when the system itself is under threat, at least among individuals high in self-deception (Jost et al., 2003). The terrifying impact of Hurricane Katrina, as well as the inept governmental responses at all levels may well have constituted such a threat, ironically strengthening support for the free market system in many individuals.

George Lakoff (2002) has argued that contemporary liberals and conservatives each have distinctive moral visions framed around metaphors of the family, and that these incompatible visions push liberals and conservatives to respond to poverty, wealth, and economic inequality in profoundly different ways. According to Lakoff, the liberal vision frames political issues around "nurturant parent morality," in which empathy for others and moral concerns for the vulnerable are salient values. In contrast, conservatives reason in terms of what Lakoff calls "strict father morality." In such a world view, self-discipline is more important than empathy, and such discipline is undermined when it is not rewarded economically and when failures of self-discipline are not punished. For Lakoff's conservatives, a moral world therefore is a hierarchical world, a meritocracy in which some people are better off than others because some have earned appropriate rewards for their behavior and others have not. Programs that reduce the suffering of the poor using tax money taken from the rich are therefore doubly misguided. They violate the tenets of the competitive, meritocratic system by reducing both justly earned punishments and justly earned rewards (Lakoff, 2002).

\section{Consequences of Attributional Patterns}

The ways people think about poverty, wealth, and economic inequality are of more than theoretical interest, because they are reflected in political views and voting behavior. Those who endorse individualistic causes for poverty and wealth are more likely to approve of restrictive welfare policies such as time limits and fingerprinting of welfare recipients to prevent fraud, while those who make structural attributions for poverty are more likely to favor universal health care, a higher minimum wage, and greater government spending on social services (Bullock, Williams, \& Limbert, 2003; Iyengar, 1990). Individualistic attributions for poverty are associated with political conservatism and with negative attitudes toward welfare, and the more poverty is perceived to be controllable by the poor, the more anger and the less pity toward poor people is expressed (Kluegel \& Smith, 1986; Zucker \& Weiner, 1993). Pity, in turn, is associated with personal readiness to help the poor (Zucker \& Weiner, 1993). Belief in structural causes for homelessness is associated with support for increased taxes to provide affordable housing (Lee, Jones, \& Lewis, 1990). Attributing wealth to ambition rather than 
to inherited privilege is associated with favoring the elimination of the dividend tax (Bullock, Fernald, \& Radley, 2005).

Individualistic attributions for poverty can be thought of as a form of scapegoating that diverts attention from inequalities that harm the middle class as well as the poor (Feagin, 1975). "Anti-poor views depoliticize the society and forestall conflict by concentrating the attention of workers on the poor at the bottom, diverting the animosity of the bulk of workers downward rather than upward" (Feagin, 1975, pp. 120-121). Nilson (1981, p. 535) suggests that "the closer that people are to poverty, the more threatened they are by those poorer than they, both economically and emotionally."

Endorsing the American achievement ideology and its individualistic attributions for poverty can be painful to those in low status positions. Goodban (1985) found that women receiving welfare payments who accepted the ideology of equal opportunity were more likely to blame themselves for their own welfare status, less likely to be assertive about their rights as welfare clients, less likely to take part in welfare activism, and more likely to experience low self-esteem. A welfare recipient can also retain her belief in the achievement ideology while personally exempting herself from blame if she finds identification with others in similar situations too painful. Seccombe, James, and Walters (1998) found that women who received welfare payments typically blamed societal factors or fate for their own economic situations, but subscribed to popular notions of other welfare mothers as lazy and unmotivated. The cost of such a strategy is that solidarity with other poor women is lost, along with opportunities to work together for political change.

\section{Class and Race Differences in Attributions for Poverty}

Even before the recent escalation of economic inequalities in the United States, Americans were more likely than many other national groups to endorse economic inequalities, lauding the rich and blaming the poor (Feather, 1974; Stern \& Searing, 1976). The sources of this American exceptionalism have intrigued historians, sociologists, and political scientists for years. Individuals generally protect selfesteem by attributing successes to themselves and failure to outside forces (Major, Kaiser, \& McCoy, 2003), but the dominant American achievement ideology demands that individuals take responsibility for their own economic fortunes in life (MacLeod, 1995).

Although American views tend to be extreme when compared to those of people in other nations, we Americans also disagree among ourselves about the causes of poverty and of economic inequality. Our reasoning is often in line with the group-serving bias (Pettigrew, 1979) and follows the principle that "support of an ideology is strongest among those who profit most from the system which the ideology explains and defends" (Rytina, Form, \& Pease, 1970, p. 715). Americans with higher incomes are the most likely to believe that the economic system is 
fundamentally just, that there is plentiful economic opportunity for all, and that the causes of both poverty and wealth are internal to the persons who experience them, while the belief that societal conditions are at least partly responsible for poverty is found most often among those with low incomes and low-status occupations (Bullock, 1999; Feagin, 1975; Feather, 1974; Kluegel \& Smith, 1986; Nilson, 1981; Rytina et al., 1970).

Older individuals, whites, and males are particularly likely to favor individualistic interpretations of poverty and wealth (Bullock, 1999; Carr \& MacLachlan, 1988; Feagin, 1975; Feather, 1974; Hunt, 1996; Kluegel \& Smith, 1986; Nilson, 1981). In contrast, blacks are much less likely than whites to believe that individual attributes alone cause poverty, wealth, or homelessness, and are more likely to endorse systemic causes for such outcomes (Feagin, 1975; Hunt, 1996; Kluegel \& Smith, 1986; Lee, Jones, \& Lewis, 1990; Nilson, 1981; Rytina et al., 1970).

Although those with low incomes would seem to suffer the most from individualistic explanations of poverty and gain the most from structural explanations for poverty and wealth, poor people may be the least familiar with alternative ideologies that legitimize such views (Nilson, 1981). Among both blacks and women, college education is associated with a greater belief in unequal opportunities for the poor, women, and blacks (Kluegel \& Smith, 1986). These authors suggest that blacks and women may use their higher education to seek out information to help them make sense of the subordination of their groups. Economically advantaged groups have no similar incentive to seek out structural explanations for disadvantage and are therefore less likely to use their educational opportunities to inform themselves of such perspectives. Interestingly, Hunt (1996) found that among blacks, having more income was associated with a decrease in individualistic beliefs about poverty, an effect not seen among other groups or in previous research. Perhaps blacks who become more affluent, gaining a "bird's eye view" of society and perhaps mixing more with whites, learn to distrust explanations for inequality that focus simply on the merit of individuals. Or perhaps the education and income of the respondents in these studies simply provided some security, making them less anxious about emotional identification with their own disadvantaged groups.

Race differences in attributional patterns were found again recently when blacks and whites were asked about the behavior of New Orleans residents at the time of the hurricane. Blacks were more likely than whites to make situational attributions for the behavior of storm victims, while whites were more likely than blacks to make dispositional attributions for the same behaviors. In responding to a national survey (Pew Research Center, 2005), more than half of the blacks surveyed (57\%) thought people who took things from homes and businesses in New Orleans were ordinary people trying to survive during an emergency, while only $38 \%$ of whites agreed. Similarly, those who committed acts of violence during the flooding were more likely to be viewed dispositionally, as criminals taking advantage of the situation, by whites (61\%) than by blacks (39\%), who were more 
likely to see them as ordinary people made desperate by their situations. Whites were more likely than blacks (32\% versus $16 \%$ ) to believe that people who stayed behind during the flooding did so because they wanted to stay. A large majority of blacks (77\%) thought most of those who stayed behind during the storm did so because they had no way to leave, while a slimmer majority of whites (58\%) interpreted their behavior in this situational way.

When asked whether the disaster showed that racial inequality remains a major problem in this country, $71 \%$ of blacks, but only $32 \%$ of whites agreed. Almost half (49\%) of those with family incomes under $\$ 20,000$ agreed with the proposition that Hurricane Katrina revealed the continuing importance of racial inequality in our country, while only a third of those with family incomes over $\$ 75,000$ endorsed this proposition (Pew Research Center, 2005).

\section{Gender}

At least in Western societies, women generally accord greater importance than men to systemic sources for poverty, such as prejudice and discrimination, exploitation of the poor, and the failure of private industry to provide sufficient jobs (Bullock, 1999; Carr \& MacLachlan, 1998; Feather, 1974; Hunt, 1996; Kluegel \& Smith, 1986). Women are more likely than men to blame society for homelessness and to support governmental action to help homeless people (Lee et al., 1990; Toro \& McDonell, 1992). Groskind (1991) found women more sympathetic than men to the plight of poor female-headed families and supportive of more generous welfare benefits. Female adolescents are more likely than their male peers to attribute unemployment to systemic causes rather than to individuals, and are less likely to believe that government support programs promote dependency (Flanagan $\&$ Tucker, 1999). Research on social dominance orientation also finds men more likely than women to support existing status hierarchies among different ethnic groups and to endorse the myths that legitimize such hierarchies, including the Protestant work ethic and the attribution of poverty to the laziness and inherent inferiority of the poor (Sidanius, Pratto, \& Rabinowitz, 1994).

When queried after Hurricane Katrina, women were only slightly more likely than men, however, (40\% versus $37 \%$ ) to believe that the hurricane showed racial inequality remained a major problem in this country (Pew Research Center, 2005).

\section{Religious Perspectives}

Religious communities may reinforce the dominant American achievement ideology or may offer alternative perspectives. At least since Weber's The Protestant Ethic and the Spirit of Capitalism, observers have argued that religious values profoundly affect the ways we think about and experience economic realities. Research over the past several decades concurs, finding differences among 
religious groups in attitudes and beliefs about the poor. Catholics were more likely than Protestants to see prejudice, discrimination, and the failure of industry to provide enough jobs as causes of poverty, while Protestants were more likely than Catholics to see lack of thrift and lack of effort by the poor themselves as causes of poverty (Feather, 1974). Individualistic causes of poverty and homelessness were endorsed more often by the religiously conservative (Fundamentalist, Mormon, Evangelical, Pietistic, and Reformed Protestant) and those who describe themselves as "very religious," while structural causes of poverty were cited more often by the religiously progressive (Jewish, Quaker, Unitarian) and the nonreligious (Kluegel \& Smith, 1986; Lee et al., 1990, Nilson, 1981).

Religious differences emerged again recently in a post-Hurricane Katrina poll in which respondents were asked whether the disaster showed that racial inequality remains a major problem in this country. Among secular respondents, $46 \%$ agreed that racial inequality was a major problem revealed by the storm. Among white Catholics, $39 \%$ agreed, as did only 25\% of white Evangelical Protestants who were surveyed (Pew Research Center, 2005).

The current political power of fundamentalist Christianity in this country would appear to strengthen the hand of those who endorse only individual causes for poverty and wealth and those who favor Lakoff's "strict father morality," while directing attention away from the structural causes of poverty and the sufferings of the poor. Recently, the Christian Coalition of Alabama helped to lead the successful opposition to new taxes in Alabama, arguing that progressive taxation punishes success, and the Christian Coalition of America chose as its top legislative priority making President Bush's 2001 federal tax cuts permanent (McKibben, 2005). Since $11 \%$ of U.S. churchgoers say they were urged by their clergy to vote in a particular way in the 2004 election, up from 6\% in 2000 (McKibben, 2005), the impact of religious views on our political direction appears to be increasing.

\section{Attributions in Childhood and Adolescence}

Several studies report differences in outlook between middle-class and working-class children paralleling those reported for adults (Dickinson and Emler, 1996; Furnham, cited in Payne \& Furnham, 1985). Leahy (1983) found uppermiddle-class children more likely to believe that economic status differences result from differences in effort and that poverty cannot be changed and less likely than children from lower socioeconomic status families to claim that the poor should not suffer. Whites were more accepting than blacks of disparities in economic inequalities and more inclined to believe that these disparities were inevitable. Blacks were more likely than whites to attribute wealth to inheritance and to violations of the law. In describing poor people, children from wealthier families were more likely to emphasize their traits, especially their effort, education, and intelligence, whereas children from lower SES families placed greater emphasis 
on their thoughts (Leahy, 1981). These lower SES children "may be more likely to take the perspective of the poor when they describe the poor, thereby "turning themselves' into the poor in their descriptions" (Leahy, 1981, p. 529). Parents may well influence the ways in which their children make sense of economic inequalities, but little research examines the processes through which such beliefs are transmitted or even examines the convergence between child and parent attributions.

In some studies, middle-class children seem more aware of class distinctions and economic inequality and more likely to give structural explanations for poverty, unemployment, and affluence than their working-class or poor peers (Flanagan, Ingram, Gallay, \& Gallay,1997; Flanagan and Tucker, 1999; Payne \& Furnham, 1985; Simmons \& Rosenberg, 1971). These authors note that middle-class children may have wider exposure to people of different socioeconomic classes and that poorer or working-class children may need to retain their faith in an open opportunity structure to avoid demoralization. Murray et al. (2002) found that among the children of poor rural African American single mothers, those who attributed poverty to social, economic, or political barriers had lower academic aspirations than children who did not attribute poverty to such societal causes.

Children's thinking about poor people, rich people, and economic inequality also changes markedly with age, increasingly reflecting the achievement ideology that explains class differences in terms of individual character. Over the elementary school years, children become more likely to prejudge the personal attributes of adults and children on the basis of their social class standing, according admiration to higher-status individuals, and expecting misbehavior from those of lower status (Baldus \& Tribe, 1978). Leahy (1981) found with greater age an increasing tendency to view the rich and the poor as different kinds of people. Adolescents tended to justify inequality by references to deservingness and expressed more fatalism about wealth and poverty than did younger children (Leahy, 1983). Leahy (1983) argued that socialization to the legitimacy of economic inequality may be "so effective that it actually offsets the application of formal operational thought to this domain of social concepts" (p. 122). The textbooks and classroom discussions available in most U.S. schools certainly endorse the view that economic success is open to all while remaining notably silent about societal barriers to such success (Apple \& Christian-Smith, 1991; Chafel, 1997; MacLeod, 1995).

Children also become less likely to reason in terms of Lakoff's "nurturant parent morality" and more likely to use something like his "strict father morality." Short (1991) found that 6-year-old English children had no doubt that differences in wealth were unfair, largely because the poor would suffer in being unable to buy food and other necessities. Their older peers, however, were more likely to consider the fairness of wealth distribution in terms of its causes, rather than its impact on people. Cummings and Taebel (1978) found that most third and sixth 
graders thought the government should do more to help poor people. By 12th grade, however, most had learned explanations for inequality "which explicitly identify individuals as the authors of their socioeconomic destinies" (p. 207).

The shift begun in childhood and adolescence, away from a compassionate view of economic justice that focuses on the prevention of suffering, toward a merit-based view of economic inequality that focuses on deservingness seems to continue into the adult years. Adults are even more likely than adolescents to favor individualistic causes for poverty and less likely to point to structural sources (Feagin, 1975; Kluegel \& Smith, 1986; Nilson, 1981). When the views of household heads were compared to those of their resident children over the age of 14 years, household heads assigned more importance than did their children to lack of thrift and proper money management, lack of effort, lack of ability and talent, and to loose morals and drunkenness as reasons for poverty, and less importance to prejudice and discrimination (Feather, 1974).

\section{Media Coverage of Hurricane Katrina}

As in other times of crisis, Americans relied largely on television for their information about Hurricane Katrina (Pew Research Center, 2005), and media coverage provided many dramatic images of desperately poor individuals and communities. Iyengar (1990) has contrasted such "episodic" media stories, in which viewers are shown particular instances of those living in poverty, with "thematic" news stories about poverty, in which the coverage is abstract and impersonal, conveying information about general trends. During the 6-year period studied by Iyengar, episodic news stories dominated network television coverage of poverty, and typical television news viewers were "nearly twice as likely to encounter news about a particular instance of a poor person than news about poverty as a collective outcome" (Iyengar, 1990, p. 22).

In his experimental studies of the impact of episodic versus thematic framing, Iyengar (1990) found that when poverty was framed thematically, individuals were more likely to assign responsibility for poverty to societal factors such as economic conditions or failed governmental programs. In contrast, when coverage of poverty focused on particular poor people, viewers were more likely to hold the poor responsible for their own economic situations. The race of those portrayed in the episodic frames also influenced the (predominantly white) viewers' reactions. When the poor person depicted was white, societal intervention was viewed more often as an appropriate response to poverty. When poor black individuals were portrayed, they were seen as more responsible for their own economic situations.

Iyengar has suggested that Americans' tendency to hold poor people responsible for their own poverty "may be due not only to dominant cultural values (e.g., individualism, self-reliance, etc.) but also to news coverage of poverty in which im- 
ages of poor people predominate" (Iyengar, 1990, pp. 28-29). The vivid, episodic coverage of Hurricane Katrina, its victims most often black, may well have had such an effect.

\section{Discussion}

Those of us who hoped that Hurricane Katrina would provide a "teachable moment," increasing our society's commitment to economic and racial equality, were disappointed. Instead, Americans reacted in divergent ways. While some of us saw the poverty and racial exclusion highlighted by the hurricane as the obvious result of societal forces crying out for correction, others focused on the flawed actions or characters of individuals, which had led to their own marginalization. Many forces contributed to this divergence in reactions, including self-serving and group-serving biases, moral frameworks, social dominance orientation, and various levels of belief in a just world and in system justification. Those most likely to downplay the problems of economic and racial inequality for groupserving reasons (economically advantaged whites), were also those most likely to have political power.

Research is needed to uncover the origins of our attributional styles and moral stances toward poverty and to locate points at which interventions might be successful in changing them. How are children socialized to think about the wealthy and the poor? How do our educational system, our media, and our religious organizations contribute to the belief that economic inequalities are just? Do children's views reflect those of their parents, and, if so, how do parents transmit their views to their children? What interventions are useful in alerting adults and children to the systemic sources of poverty and inequality? Do such interventions promote greater compassion and respect for poor people? Do they lead to increases in charitable giving, changed voting behavior, or other political action?

More research is also needed to explore the ways in which poor men, women, and children cope with the contempt they experience for their economic status and with the pervasive achievement ideology that promises economic security if one simply works hard enough. If individuals accept this ideology, how do they maintain self-esteem? If they reject the ideology, how do they maintain selfefficacy and the hope that they will someday escape their current poverty?

A growing body of research suggests that economic inequality in the United States may be harmful to our democracy, distorting our governmental priorities, reducing our trust in each other, and diminishing our cohesiveness as a society. Those who are committed to social and economic equality can work on projects such as the retention of inheritance taxes and shareholder rejection of immense corporate salaries. Such battles are difficult ones because of the political power of wealthy individuals and corporations. United for a Fair Economy (www.FairEconomy.org) is one group that creatively publicizes the growing economic divide in this country 
and mobilizes support for efforts to achieve greater economic equality. Through its publications, curricula for young people, speakers, rallies, workshops, and street theater, it has built coalitions to fight for progressive taxes and against corporate abuses such as predatory lending practices and excessive corporate salaries.

Just as it took a confluence of preexisting geography, unusual weather conditions, environmental degradation, neglect of infrastructure, racism, classism, and presidential cronyism to produce the remarkable devastation achieved by Hurricane Katrina, it has taken a "perfect storm" of history, politics, economics, intergroup dynamics, attributional biases, and religious revivalism to produce the contours of our response to the economic inequalities revealed by Hurricane Katrina. Those who hope to reconfigure U.S. responses to poverty and to economic and racial inequalities have a difficult and an important mission.

\section{References}

Apple, M. W. \& Christian-Smith, L. K. (Eds.) (1991). The politics of the textbook. New York: Routledge. Baldus, B. \& Tribe, V. (1978). The development of perceptions and evaluations of social inequality among public school children. Canadian Review of Sociology and Anthropology, 15, 5060.

Bartels, L. (2004, May 17). Unenlightened self-interest. American Prospect Online. Retrieved from http://www.prospect.org/print-friendly/print/v8/32/schlozman-k.html.

Bartels, L. M. (2005, August). Economic inequality and political representation. Unpublished paper, Princeton University.

Bullock, H. E. (1999). Attributions for poverty: A comparison of middle-class and welfare recipient attitudes. Journal of Applied Social Psychology, 29, 2059-2082.

Bullock, H. E., Fernald, J. L. \& Radley, A. (2005). Predicting support for eliminating the dividend tax:The role of framing and attributions for wealth. Analyses of Social Issues and Public Policy, 5,1 .

Bullock, H. E., Williams, W. R., \& Limbert, W. M. (2003). Predicting support for welfare policies: The impact of attributions and beliefs about inequality. Journal of Poverty, 7, 35-56.

Carr, S. C. \& MacLachlan, M. (1998). Actors, observers, and attributions for Third World poverty: Contrasting perspectives from Malawi and Australia. The Journal of Social Psychology, 138, 189-202.

Chafel, J. A. (1997). Schooling, the hidden curriculum, and children's conceptions of poverty. Social Policy Report, 11, 1-18.

Cummings, S. \& Taebel, D. (1978). The economic socialization of children: A neo- Marxist analysis. Social Problems, 198-210.

Della Fave, L. R. (1980). The meek shall not inherit the earth: Self-evaluation and the legitimacy of stratification. American Sociological Review, 45, 955-971.

DeParle, J. (2005, October 11). Liberal hopes ebb in post-storm poverty debate. New York Times, p. 1.

Dickinson, J. \& Emler, N. (1996). In P. Lunt \& A. Furnham (Eds.) Economic socialization: The economic beliefs and behaviors of young people. Cheltenham, UK: Edward Elgar.

Feagin, J. R. (1975). Subordinating the poor: Welfare and American beliefs. Englewood Cliffs, NJ: Prentice-Hall.

Feather, N. T. (1974). Explanations of poverty in Australian and American samples: The person, society, or fate? Australian Journal of Psychology, 26, 199-216.

Flanagan, C. A., Ingram, P., Gallay, E. M., \& Gallay, E. E. (1997). Why are people poor? Social conditions and adolescents' interpretations of the social contract. In R. E. Taylor \& M. C. Wang (Eds.) Social and emotional adjustment and family relations in ethnic minority families. Mahway, N J: Erlbaum. 
Flanagan, C. A. \& Tucker, C. J. (1999). Adolescents' explanations for political issues: Concordance with their views of self and society. Developmental Psychology, 35, 1198-1209.

Goodban, N. (1985). The psychological impact of being on welfare. Social Service Review, 59, 403422.

Groskind, F. (1991). Public reactions to poor families: Characteristics that influence attitudes toward assistance. Social Work, 36, 446-453.

Grusky, D. B. \& Ryo, E. (2006, March). Did Katrina recalibrate attitudes toward poverty and inequality? A test of the "Dirty Little Secret" hypothesis. Unpublished paper. Stanford University.

Hunt, M. O. (1996). The individual, society, or both? A comparison of Black, Latino, and White beliefs about the causes of poverty. Social Forces, 75, 293-322.

Iyengar, S. (1990). Framing responsibility for political issues: The case of poverty. Political Behavior, $12,19-40$.

Jost, J. T., Banaji, M. R., \& Nosek, B. A. (2004). A decade of System Justification Theory: Accumulated evidence of conscious and unconscious bolstering of the status quo. Political Psychology, 25, 881-919.

Jost, J. T., Blount, S., Pfeffer, J., \& Hunyady, G. (2003). Fair market ideology: Its cognitive-motivational underpinnings. Research in Organizational Behavior, 25, 53-91.

Jost, J. T. \& Hunyady, O. (2005). Antecedents and consequences of system-justifying ideologies. Current Directions in Psychological Science, 14, 260-265.

Kaplan, G. A., Pamuk, E. R., Lynch, J. W., Cohen, R. D., \& Balfour, J. L. (1996). Inequality in income and mortality in the United States: Analysis of mortality and potential pathways. British Medical Journal, 312, 999-1003.

Kawachi, I. (1999). Social capital and community effects on population and individual health. Annals of the New York Academy of Sciences, 896, 1-11.

Kawachi, I. \& Kennedy, B. P. (1999). Income inequality and health: Pathways and mechanisms. Health Services Research, 34, 215-227.

Kawachi, I., Kennedy, B. P., Lochner, K., \& Prothrow-Stith, D. (1997). Social capital, income inequality, and mortality. American Journal of Public Health, 87, 1491-1498.

Kluegel, J. R. \& Smith, E. R. (1986). Beliefs about inequality: Americans' views of what is and what ought to be. New York: Aldine De Gruyter.

Lakoff, G. (2002). Moral politics: How liberals and conservatives think. Chicago: University of Chicago Press.

Leahy, R. L. (1981). The development of the conception of economic inequality: I. Descriptions and comparisons of rich and poor people. Child Development, 52, 523-532.

Leahy, R. L. (1983). Development of the conception of economic inequality: II. Explanations, justifications, and concepts of social mobility and change. Developmental Psychology, 19, 111-125.

Lee, B. A., Jones, S. H., \& Lewis, D. W. (1990). Public beliefs about the causes of homelessness. Social Forces, 69, 253-265.

Lerner, M. J. \& Miller, D. T. (1978). Just world research and the attribution process: Looking back and ahead. Psychological Bulletin, 85, 1030-1051.

Lerner, S. (2005, November 7). Robbing the poor. The Nation, 281, 6-8.

Lonergan, R. (1941). Brandeis' glorious career ended. Labor, $23,4$.

McKibben, B. (August, 2005). The Christian paradox: How a faithful nation gets Jesus wrong. Harper's Magazine, 31-37.

MacLeod, J. (1995). Ain't no makin' it: Aspirations and attainment in a low-income neighborhood. Boulder: Westview.

Major, B., Kaiser, C. R., \& McCoy, S. K. (2003). It's not my fault: When and why attributions to prejudice protect self-esteem. Personality and Social Psychology Bulletin, 29, 772-781.

Mishel, L., Bernstein, J., \& Allegretto, S. (2005). The state of working America 2004-05. Ithaca, NY: Cornell University Press.

Murray, V. M., Brody, G. H., Brown, A., Wisenbaker, J., Cutrona, C. E., \& Simons, R. L. (2002). Linking employment status, maternal psychological well-being, parenting, and children's attributions about poverty in families receiving government assistance. Family Relations, 51, 112-120.

Nilson, L. B. (1981). Reconsidering ideological lines: Beliefs about poverty in America. The Sociological Quarterly, 22, 531-548. 
Payne, M. \& Furnham, A. (1985). Explaining the causes of poverty in the West Indies: A cross-cultural comparison. Journal of Economic Psychology, 6, 215-229.

Pettigrew, T. F. (1979). The ultimate attribution error: Extending Allport's cognitive analysis of prejudice. Personality and Social Psychology Bulletin, 5, 461-476.

Pew Research Center (2005, September 8). Huge racial divide over Katrina and its consequences. Unpublished news release.

Putnam, R. D. (1993). Making democracy work: Civic traditions in modern Italy. Princeton: Princeton University Press.

Robinson, R. V. \& Bell, W. (1978). Equality, success, and social justice in England and The United States. American Sociological Review, 43, 125-143.

Rytina, J. H., Form, W. H., \& Pease, J. (1970). Income and stratification ideology: Beliefs about the American opportunity structure. American Journal of Sociology, 75, 703-716.

Sapolsky, R. M. (2004). Why zebras don't get ulcers (Third Edition). New York: Henry Holt.

Schlozman, K. L., Brady, H. E., \& Verba, S. (1997, May 1-June 1). The big tilt: Participatory inequality in America. The American Prospect, 8 (32).

Seccombe, K., James, D., Walters, K. B. (1998). "They think you ain't much of nothing": The social construction of the Welfare mother. Journal of Marriage and the Family, 60, 849-865.

Short, G. (1991). Perceptions of inequality: Primary school children's discourse on social class. Educational Studies, 17, 89-106.

Sidanius, J. \& Pratto, F. (1999). Social Dominance: An intergroup theory of social hierarchy and oppression. New York: Cambridge University Press.

Sidanius, J., Pratto, F., \& Rabinowitz, J. L. (1994). Gender, ethnic status, and ideological asymmetry: A social dominance interpretation. Journal of Cross-Cultural Psychology, 25, 194-216.

Simmons, R. G. \& Rosenberg, M. (1971). Functions of children's perceptions of the stratification system. American Sociological Review, 36, 235-249.

Stern, A. J. \& Searing, D. D. (1976). The stratification beliefs of English and American adolescents. British Journal of Political Science, 6, 177-201.

Toro, P. A. \& McDonell, D. M. (1992). Beliefs, attitudes, and knowledge about homelessness: A survey of the general public. 3-80. American Journal of Community Psychology, 20, 53-80.

Verba, S., Kelman, S., Orren, G. R., Miyake, I., Watanuki, J., Kabashima, I., \& Ferree, G. D. (1987). Elites and the idea of equality: A comparison of Japan, Sweden, and the United States. Cambridge, MA: Harvard University Press.

Wilkinson, R. G. (1996). Unhealthy societies: The afflictions of inequality. London: Routledge.

Zucker, G. S. \& Weiner, B. (1993). Conservatism and perceptions of poverty: An attributional analysis. Journal of Applied Social Psychology, 23, 925-943.

DEBORAH BELLE is professor of Psychology at Boston University. Her books include Lives in Stress: Women and Depression and The After-School Lives of Children: Alone and with Others While Parents Work. Her current research explores the ways in which families talk together about poverty, wealth, and economic inequalities. 